\title{
28 Research Square \\ Fishing in your backyard: otters that prey on urban resources
}

\author{
Jesus Duarte ( $\boldsymbol{\nabla}$ jddofitecma@gmail.com ) \\ Ofitecma Marbella https://orcid.org/0000-0002-4952-154X \\ Diego Rodríguez \\ Ofitecma Marbella \\ Miguel Ángel Farfán \\ University of Malaga: Universidad de Malaga \\ Julia E. Fa \\ Manchester University
}

\section{Research Article}

Keywords: otter, boldness behavior, prey depletion, urban areas

Posted Date: June 17th, 2021

DOl: https://doi.org/10.21203/rs.3.rs-415007/v1

License: () (7) This work is licensed under a Creative Commons Attribution 4.0 International License. Read Full License 


\section{Abstract}

We monitored the incidence of predation behavior in Eurasian otters (Lutra lutra) from urban ponds in southern Spain, following reports of the mustelids' presence in various urban locations. In one of the case studies, 30 small common carp and 35 Koi fish were released in May 2017 and April 2018, respectively, into two different ponds. Otters extensively predated on these fish over a period of 75-80 days. Only two small carp (6.6\%) survived in one of the ponds and 10 Koi fish (28.5\%) in the other. The surviving Koi were relocated. We determined that fish survival functions and mortality rates between these two years were not significantly different. At the second urban location, otters extensively predated on Iberian frogs over a period of 5-6 days in May 2018, left the area, and repeated this pattern in May 2019. Finally, at the third urban location, otters consumed 20 goldfish in 16 days in August 2018. Our results indicate that available food resources in urban settings can become a viable option for certain bold individuals of wildlife species and that otters appear to explore urban habitats when it suits them. Appropriate management and damage control strategies are therefore needed to ensure the survival of this protected species in case food resources in the wild become limited and urban raids become habitual.

\section{Introduction}

Wild species are more frequently found in urban environments (Gloor et al. 2001; Atchison and Rodewald 2006; Duarte et al. 2015; Castillo-Contreras et al. 2018). As human activities such as urbanization invade natural areas, some wildlife species consequently adapt to these changes, primarily by finding efficient ways to utilize the newly available resources whilst continuing to inhabit wild habitats (Rodewald and Gehrt 2014).

The adaptation of wildlife species to urban environments can result in changes to their physiology, reproductive strategies, and overall fitness. In most cases, the species will adapt its behavior to the urban environment (Isaakson et al. 2018). One of the common consequences of a species entering a novel environment is an increase in boldness (Charmantier et al. 2017). Some animals may display more explorative behaviors and be less fearful of humans (Carrete and Tella 2017; Martínez-Abraín et al. 2018). This allows animals to access a more predictable environment typical of urban settings, where they may be able to find more abundant resources and subsidies (Martínez-Abraín and Jiménez 2016; Rodewald and Arcese 2017).

The probability that an urban setting is visited by a wild species will depend on the overall layout and design of this environment, i.e., a matrix of natural habitat patches within built-up developments is more likely to be invaded (Marzluff and Rodewald 2008). The type of vegetation and the presence of water and food are also important features that can entice wild animals. Urban parks usually meet these characteristics by providing a source of anthropogenic foods (Thieme et al. 2015).

The Eurasian otter (Lutra lutra) lives in Mediterranean regions and is a semi-aquatic carnivore with a wide and diversified diet. This species can be a piscivorous specialist as well as behave as a more generalist 
and opportunistic predator, depending on the prevailing environmental and climatic conditions (Clavero et al. 2003). In southern Spain, otters consume seasonally available food resources during periods of scarcity (i.e., during droughts or low water flows and levels) and will search for food in places with available water. Such water reservoirs, which become "emergency pantries," include ponds, ditches, river mouths, dams, weirs, or artificial lagoons in golf courses (Ruiz-Olmo et al. 2007; Ruiz-Olmo and Jiménez 2008a; Duarte et al. 2011). Otters typically catch and consume a variety of fishes, amphibians, reptiles, and crayfish (Clavero et al. 2005, 2007).

The presence of otters in the urban environments of southern Spain appears to have increased over the past two decades. In 1998, an otter was found road-killed on an urban road in Marbella $\left(36^{\circ} 29^{\prime} \mathrm{N}, 4^{\circ}\right.$ $57^{\prime}$ W; Rodríguez, pers. obs.). In 2001, one was spotted in a lagoon at the "La Quinta" golf course ( $36^{\circ}$ $30^{\prime} \mathrm{N}, 4^{\circ} 59^{\prime} \mathrm{W}$; Rodríguez, pers. obs.). In 2005, sightings of the mustelid were reported in three golf courses (Duarte and Rubio 2005) located in peri-urban areas. In 2007, two otters were found road-killed on an urban road $\left(36^{\circ} 30^{\prime} \mathrm{N}, 5^{\circ} 00^{\prime} \mathrm{W}\right.$ ) in Benahavís, Málaga (Guardia Civil, pers. comm.; a third was found on the same road in 2008 (Duarte 2008). This road borders a golf course where otters have been sighted. In 2010, an otter depleted all the fish from "La Represa" urban park, located in the center of Marbella city in Málaga (Duarte, pers. obs.). In 2010, we found evidence of otters preying on carp and freshwater turtles in the artificial lakes of a golf course (Duarte et al. 2011). Between 2015 and 2017, an otter frequently preyed on frogs from an artificial pond in the garden of an ex-urban dwelling near Benahavís (J.V. García, pers. comm.). In 2017, a gardener reported the presence of an otter in the Japanese garden of a dwelling located in the urban area of Nueva Andalucía (Marbella); this garden contained an artificial pond populated by fish (Rodríguez, pers. obs.). An otter was also spotted crossing a street in the same area (Rodríguez, pers. comm.). In 2019-2020, an otter was captured on camera walking along an avenue in the city of Tarifa (https://www.club-caza.com/actualidad/actualver.asp? $\mathrm{nn}=10274$ ), and sightings of otters were also frequently reported in other Spanish cities (https://elpais.com/sociedad/2019/06/20/actualidad/1561007625_268315.html; https://www.laverdad.es/lospiesenlatierra/noticias/nutria-centro-murcia-20190520145024-nt.html).

The present study was aimed at monitoring otters in three localities where they were previously spotted, to assess their predation strategies on urban preys and their use of artificial or constructed habitats in cities. We further discuss the role of urban environments in providing otters with resources and the implications for damage control. From a broader point of view, we attempt to understand why otters may be accessing urban resources.

\section{Material \& Methods}

\section{Study area}

The study area comprised of three urban localities. The first was an urban park, "Torre Leoneras," in the town of Benahavís (Málaga, South of Spain; $36^{\circ} 31^{\prime} \mathrm{N}, 5^{\circ} 02^{\prime} \mathrm{W}$ ), with a surface area of $8,400 \mathrm{~m}^{2}$ and two ponds. The nearest inhabited areas were $128 \mathrm{~m}$ and $35 \mathrm{~m}$ away from the ponds and the park perimeter, 
respectively. One of the ponds spanned $300 \mathrm{~m}^{2}$ with no perimeter fence. The other spanned $140 \mathrm{~m}^{2}$ and was enclosed by a metallic fence 1.5-m high (Hercules rigid fence panels, $200 \times 50 \mathrm{~mm}$ mesh light). The depth of the ponds did not exceed $0.5 \mathrm{~m}$. The Town Hall introduced the common carp in both ponds. The carp is a widespread domesticated freshwater fish, common in eutrophic and introduced environments worldwide, and is often an invasive species (Koehn 2004).

On May 1, 2017, a total of 30 smaller sized common carp $(16.2 \pm 0.5 \mathrm{~cm}$ long from head to tail; mean \pm SE) were introduced in the larger pond. In late April 2018, 35 Koi fish (also called "brocaded carp"), a colored and larger variety of the common carp from Japan, were released in the smaller pond. These fish measured $72.6 \pm 0.8 \mathrm{~cm}$ from head to tail.

The park was hedged around its perimeter and fenced with Hercules rigid panels. Vegetation inside the park was mainly composed of native plant species such as carob (Ceratonia siliqua), willow (Salix pedicellata), maritime pine (Pinus pinaster), wild olive tree (Olea europeae var. sy/vestris), and black poplar (Populus nigra). Oleander (Nerium oleander), as well as the perennial and decorative papyrus sedge (Cyperus papyrus), were typically found around each pond. A weeping willow (Salix babylonica) also grew near the smaller pond.

The park was located $25 \mathrm{~m}$ from the Guadalmina river bank. This river was declared SAC (Special Area of Conservation of the Nature 2000 network) to protect the otters, between other endangered species. It was bordered with vegetation consisting of willows and other species also found inside the park. An irrigation ditch in the river bank furthest from the park linked to a small dam $2 \mathrm{~km}$ upstream from the park and a cultivated area near the river mouth ( $7 \mathrm{~km}$ away from the park). The river has a reduced water channel during the summer, with dry stretches interspersed with small ponds where fish tend to concentrate. The irrigation ditch always contains water during summer, although not enough for fish to survive. Most of the common fish species in the Guadalmina river are Luciobarbus sclateri, Squalius malacitanus and Chondrostoma willkommii. Mediterranean turtles (Mauremys leprosa), frogs [predominantly Perez's frogs (Pelophylax perezi)], and crayfish (Procambarus clarkii) were also found in the river and the ditch.

The second location was an ex-urban dwelling near Benahavís in the "Campanillas" district of Málaga $\left(36^{\circ} 31^{\prime} \mathrm{N}, 5^{\circ} 01^{\prime} \mathrm{W}\right)$, on a private estate surrounded by a forest matrix in which homes, gardens, and green zones were interspersed. The estate included a big garden with a $91-\mathrm{m}^{2}$ artificial pond less than $1 \mathrm{~m}$ deep. The garden was surrounded by Mediterranean scrubland including carob trees, cork oaks (Quercus suber), and maritime pines. Two small streams lined the property. To the East was "La Leche" stream, which crossed the "Los Arqueros" golf course, where otters were reported. To the West was the "Puerco" stream, which crossed the other golf course and flowed out at "La Leche" reservoir, similar to the eastern stream. Otters were present in this reservoir (Duarte and Rodríguez, pers. obs.) which was $2.2 \mathrm{~km}$ away from the dwelling. The eastern and western streams were $190 \mathrm{~m}$ and $280 \mathrm{~m}$ away from the pond, respectively. Although it did not contain fish, the garden lake was home to the Iberian water frog (Pelophylax perezi), Mediterranean tree frog (Hyla meridionalis), and crayfish. 
Lastly, the third locality was a residential complex of chalets located in the "Nueva Andalucía" district of the city of Marbella $\left(36^{\circ} 20^{\prime} \mathrm{N}, 4^{\circ} 57^{\prime} \mathrm{W}\right)$. This area is peri-urban and surrounded by several golf courses wherein dwellings are interspersed with green zones and sports facilities. One of the properties boasted a Japanese garden with a $60-\mathrm{m}^{2}$ artificial pond less than $0.5 \mathrm{~m}$ deep, in which the owner would release goldfish (Carassius auratus) less than $15 \mathrm{~cm}$ long from head to tail. Iberian water frogs and Mediterranean tree frogs were also present in the garden. This lake was located $60 \mathrm{~m}$ away from the "Benavolá" stream, a narrow urban watercourse that crosses one golf course and connects the two small reservoirs of "El Ángel" and "Lagomar." Otters were present in both reservoirs (Duarte and Rodríguez, obs. pers.) and frequently sighted in the "Benavolá" stream. The stream is bordered by willows (Salix sp.), salt cedars (Tamarix sp.), and other ornamental garden trees. The pond contained water lilies (Nymphaea alba).

\section{Sampling Process}

Following each carp release in the "Torre Leoneras" park, we monitored the ponds daily-aided by the park's gardening staff- by counting the number of fish and any potential predation episodes. Once we detected a possible predation event (e.g., a dead fish, its remains, or a decline in the number of carps in the ponds), we installed three camera traps (using Browning Strike Force HD cameras) around the perimeters of each pond, to identify the predators. Direct sightings of predators in the ponds were recorded, and spraints were sampled daily. The monitoring process was halted when the predation episodes ended (around mid-October).

We estimated carp survival rates using the Kaplan-Meier product-limit (White and Garrot 1990). We compared the survival curves in both ponds using the Kolmogorov-Smirnov (Sokal and Rohlf 1996) and Kruskal-Wallis tests for non-normalized data, to test for differences in the predation rates between the monitored years (Fowler and Cohen 1992).

We started to survey the "Campanillas" pond in late March 2018. With the help of the property gardening staff, this was carried out daily by monitoring the lake shores and searching for otter spraints and amphibian remains. The sampling procedure was performed until the remains stopped appearing (around mid-May) and was repeated in March 2019. We counted the number of amphibian remains found every day until mid-May when they were no longer detected.

The "Nueva Andalucía" pond was also monitored with the help of the property gardening staff. During the first episode (August 2017) they detected the presence of an otter following a release of goldfish. The owner released goldfish once again in July 2018. The otter's presence and any potential disappearance of fish were monitored daily from the day of this release to the end of August when the goldfish resource became depleted. We considered the presence of otter spraints, scales, or fish remains at the pond shores, as well as direct otter observation, as parameters for data collection. The number of goldfish in the pond was counted daily. Because the owner did not release more fish in 2019, this was the only sampling event at this pond. 
The values obtained are shown as means with their standard errors. All experiments complied with the current laws on wildlife care, protection, and conservation in Spain and the Community of Andalucía.

\section{Results}

\section{"Torre Leoneras" park}

Monitoring of the pond containing the common carp (i.e., the large pond) began from the release of the fish on May 1, 2017, when the fish were released, until October 1, 2017 (i.e., for 148 days). Only two carp (i.e., $6.6 \%$ of the released fish) survived to the end of this period. The predators observed in the area included kingfishers (Alcedo atthis), grey herons (Ardea cinerea) and otters, although we were unable to attribute the number of fish caught to each of these predators.

Monitoring of the pond containing Koi fish (i.e., the small pond) took place for up to 157 days (i.e., from April until October 1, 2018). Only 10 Koi fish (i.e., 28.5\%) survived by the end of this period. Otters were the only predator observed and were responsible for all the catches. Predation in this pond stopped when the park managers decided to relocate the surviving Koi fish to a new pond (more than $3 \mathrm{~km}$ away from the park), following various unsuccessful attempts to stop predation.

Predation events started in mid-July (i.e., 80 days after the release) in both ponds, always after a decrease in the river water level. For 75-80 days, otters predated extensively on the carp (Fig. 1), killing up to three fish per night (instead of the usual one), similar to Koi fish, during the same incursion into the park, always at night. Kaplan-Meir survival functions were not significantly different (KolmogorovSmirnov test, $p=0.794$ ) between ponds. No significant difference was detected in mortality rates between the assessed years (Kruskal-Wallis test, $\mathrm{Chi}^{2}=0.258$; d.f. $=1 ; \mathrm{p}=0.612$ ).

We found no fish carcasses by the large pond but did detect fish scales and spraints near the pond border, perhaps because of the small size of the fish involved. However, otters abandoned up to 10 carcasses in the grass (10 $\mathrm{m}$ around the small pond) and at least two in the nearby riverbank outside the park. Two of the carcasses were almost completely consumed (Fig. 2); the remaining eight were partially eaten (Fig. 3), either with their necks bitten or only skinned. It should be noted that otters successfully avoided the Hercules fences in the park. In some cases, we found evidence of digging under the fence; in others, we observed hair on the fence, which suggested that otters were attempting to climb up.

\section{"Campanillas" and "Nueva Andalucía" ponds}

In "Campanillas," the first survey began on March 20, 2018, and lasted until May 15, 2018. During this period, we found 31 frog skins at the pond shores (May 4 to May 8). Otters preyed on $10.3 \pm 0.19$ frogs per day during these five days. The survey was repeated in 2019, from March 20 to May 20, and 43 frog skins were found at the pond shores (May 10 to May 15). During these six days, otters preyed on $12.3 \pm$ 0.37 frogs per day. We also found otter spraints during the survey periods. The sampling process was stopped when frog remains were no longer found at the pond shores. 
In the "Nueva Andalucía" pond, the survey started on July 18, 2018, following the release of 20 goldfish ( $15.7 \pm 0.3 \mathrm{~cm}$ head to tail length). The otter was detected first on August 2, when the water lilies appeared shattered. Between August 2 and August 17, the otter depleted the 20 goldfish (Fig. 4) and departed hereafter. Otter spraints, as well as fish scales and remains, were observed at the pond shores. It was not possible to carry out a new survey in 2019 , as the owner did not release more fish in the pond.

\section{Discussion \& Conclusions}

Our results suggest that otters underwent episodes of extensive predation in urban settings. Similar predation events were reported for reptiles (García and Ayres 2007) and amphibians (Lizana and PérezMellado 1990; Alarcos et al. 2006; Cogâlniceanu et al. 2010), although these events always occurred in natural ecosystems. In urban areas, there are no references-as far as we know-of otter raids in the scientific literature. Nevertheless, the frequency of otters entering urban areas is higher than it seems, as reported in the press (The Columbia Valley Pioneer 2019; The Global News 2020; The Star 2020; The Wiltshire Times 2020). Otters may, therefore, be following a similar trend to other wildlife by visiting urban landscapes more often (Shochat et al. 2010; Martínez-Abraín et al. 2018).

In "Torre Leoneras," predation on carps in one pond cannot be entirely attributed to otters. The observed presence of kingfishers and herons around the pond, although not verified, suggested that these birds may also have participated in fish predation. However, the park was very popular and frequented by visitors during the day so the predation pressure exerted by daytime predators must have been very low. Further, in the case of kingfishers, predation cases, if happened, should have been limited to small fishes. These species can develop a feeding association with otters, which may have benefited from their presence (Mougeot and Rodríguez-Ramiro 2019). Although the small size of the carps made it difficult to find predation signs, fish scales found near the pond and the spraints containing scales confirm that otters actively predated on the fish.

Only otters raided the pond containing Koi fish. Photo trapping and direct sightings, as well as the spraints and carcasses that we found, indicated that otters killed the fish. The otters did not fully consume most of the fish; instead, bites in the neck and skinning suggest that they searched for the fattiest tissues. Several of the carcasses were found away from the pond and abandoned on the park grass. Some fish were found trapped in the pond fence as the otter possibly attempted to take them out. This pattern, together with the fact that up to three fishes were killed on the same night, suggests the presence of an otter with cubs, as these are usually very efficient at exploiting small rich food patches within its territory (Ruiz-Olmo et al. 2005). Although our study period concurred with the otter's breeding season (Ruiz-Olmo et al. 2003; Ruiz-Olmo and Jiménez 2008b), our data did not indicate the presence of cubs and could simply suggest that the otters were eating the most energy-giving parts of the fish and leaving the remaining parts (Ruiz-Olmo et al. 1998) in a setting where prey was easily available. Only rarely otters leave any part of the prey (Kruuk 2006) and usually everything is eaten. Nevertheless, Carss et al. (1990) showed that when a large prey is caught, as our Koi fishes, otters eat an average and abandon the rest, including head, tail and vertebrate. This is just the pattern we observed. 
It was obvious that otters entered the park from the nearby river. We located carcasses close to the park perimeter and on the riverbank outside the park. Interestingly, the otters could overcome the obstacle posed by the fences either by digging under or attempting to climb over them. Although park managers sealed the base of the pond fence with concrete to avoid raids, the killings continued to occur.

Predation events in the ponds were not concentrated within a short time interval, and the otters' presence was constant. During their time in the park, they had access to alternative preys (e.g., small fish, crayfish, amphibians, and terrapins) both in some of the river ponds and in the irrigation ditch. Nevertheless, some otters-or maybe always the same individual-focused on the park ponds. It was likely more profitable to catch energy-rich fish in a small and shallow artificial pond, where they could not escape (Llinares et al. 2019; Martínez-Abraín et al. 2020) than to search for other preys in the river. As such, the park was for otters the closest thing to a well-stocked pantry.

In the "Campanillas" pond, we determined that the pattern of predation fitted that of an otter (Clavero et al. 2005), and also found its spraints. Although we did not count the number of frogs in the pond, the otter seems to deplete most of the existing amphibians by systemically visiting their habitat over a few days, probably until was no longer profitable to catch the remaining individuals. This behavior was repeated in two consecutive years and, as far as we know, also occurred in previous years, according to the estate staff. This implies that otters either systematically patrol their entire territory or remember places with a potentially specific abundance of resources at any given time. It should be noted that although this pond was located near two streams, these were low-flow and of little importance. However, these streams are connected to the artificial lakes in the golf course, as well as to a reservoir, and we confirmed the presence of otters in all these water bodies. An added consideration is that the predation episodes always occur in May, during which the summer drought has yet to begin. Therefore, the otter's behavior may not be due to prey scarcity but to other reasons related to prey concentration. According to Díaz-Paniagua (1992) and Richter-Boix et al. (2007), the reproductive period of the lberian frog is delayed compared to that of other species and concentrated to late spring in the south of Spain. This period fits with our predation episodes in a pond that met all the requirements as the optimal breeding habitat (DíazPaniagua 1983, 1990) and in which numerous individuals were concentrated for amplexus and spawning. Further, when otters know about high seasonal densities of amphibians, easy to capture, it is shown they deplete them (Morales et al. 1998), especially in lentic ecosystems.

Regrettably, we were unable to obtain data from more than one season in the third urban pond. However, the pattern observed was similar to that of the other ponds. As otters were often in the stream close to the pond, they may have noticed the fish in the pond and depleted them in a short time. There was probably a similar occurrence in the previous season (i.e., during the first release of fish) when the property owner saw an otter eating a fish in the garden.

Kruunk (1995) proposed that the otter is a food-limited species, adaptable to almost any habitat with abundant prey. Otters, therefore, depend more on prey availability than directly on the type of prey itself, raising the question of whether otters prey until a depletion of resources (Delibes et al. 2000; Ruiz-Olmo et 
al. 2007) or until the resources reach a density that does not favor the risk of predation (Ruiz-Olmo et al. 2001). Both these situations have been observed in Mediterranean otters, as well as in our case studies. In the urban park, small carps were caught until they were almost depleted. Moreover, if park managers had not relocated the surviving Koi fish, they would have likely been depleted. We cannot be sure of the complete depletion of frogs in the "Campanillas" pond as some could have survived; however, a total depletion was confirmed in the third urban pond.

According to our data, otters are adapting to more urban conditions, from a species that was always linked to natural environments and clean waterways. Further, otters were considered a bioindicator of water quality (Jiménez et al. 2008). However, we have proof of their presence in streams and ponds located in urban regions where the water quality would not be indicative of this bioindicator's habitat (e.g., presence of fecal discharge, eutrophic waters, and chemical carry-over from golf course treatments). Yet, the otter uses them. These bold mustelids have likely discovered new rich resource habitat patches in urban environments that they can exploit as required. Alternatively, urban environments may have expanded so much to the point that they have reached the doors of the otter's natural habitats. In the latter case, it would be abnormal for an opportunistic mammal such as the otter not to exploit the resources readily available to them. Our data confirm that the otter can comfortably hunt in urban and peri-urban environments, and agree with the pattern of recovery and increase in populations that otters typically display in Spain (Jiménez et al. 2008). These authors also relate these occurrences, among other factors, to the appearance of new favorable and anthropogenic habitats.

Finally, as urbanization modifies the trophic dynamics by increasing the availability of anthropogenic food, wildlife communities are also altered, and predator numbers may increase (Fischer et al. 2012). The urbanization of endangered or protected species will likely become more frequent as changes in the natural and man-made environments occur. It is therefore imperative to ensure the survival of these species in the wild by protecting their natural habitats, as well as develop and implement adequate management and damage control strategies within urban settings, as invasions into semi-natural urban environments are likely to occur more often. These substitution habitats may allow for similar or higher population growth rates than those in original habitats (Martínez-Abraín and Jiménez, 2016), thereby becoming a source of conflict. In fact, before relocating the Koi fish, park managers attempted to illegally snare and trap the predators. The citizen pressure led them to look for other solutions, highlighting the need for new policies for wildlife management in a changing world (Martínez-Abraín et al. 2019).

\section{Declarations}

\section{Acknowledgements}

We would like to thank the Torre Leoneras park gardening staff their help during the monitoring period. Diego Zumaquero, environmental technician at the Benahavis Tawn Hall, put us on notice about the fish releases at the park. Juan Vicente García, manager of the Campanillas estate, told us about frog remains 
in the garden of the estate, let us to visit the pond and facilitated sampling. Finally, the manager of the Nueva Andalucía dwelling allowed us to visit the place and monitoring.

\section{Funding}

This project did not use public funding. It was funded with own means of the company Ofitecma Marbella S.L.

\section{Authors' information}

\section{Affiliations}

\section{Ofitecma Marbella, Av. Ramón y Cajal 17, 29601 Marbella, Málaga, Spain}

Jesús Duarte \& Diego Rodríguez

Dept. of Animal Biology, University of Málaga, Fac. Sciences, Campus de Teatinos, 29001 Málaga, Spain Miguel Ángel Farfán

Dept. of Natural Sciences, Manchester Metropolitan University, John Dalton Building, Manchester Campus, Manchester, M15 6BH, United Kingdom

Julia E. Fa

\section{Contributions}

JD and DR conceived the research and collected the data; JD and MAF analyzed the data; and JD, MAF, DR and JF wrote the paper.

\section{Corresponding author}

Correspondence to Jesus Duarte (jddofitecma@gmail.com)

\section{Ethics declarations}

The authors declare that they have no conflict of interest.

All authors were informed about the submission of the work to Urban Ecosystems Journal, agreed to participate, gave final approval for publication in the journal and approved the ethics of methods applied during the work. All data of this work are available at Ofitecma Marbella database.

\section{References}

Alarcos G, Ortiz ME, Fernández MJ, Lizana M (2006) Depredación del gallipato (Pleurodeles walt) por nutria en los Arribes del Duero, Salamanca. Bol Asoc Herpetol Esp 17(2):85-88 
Atchison KA, Rodewald AD (2006) The value or urban forests to wintering birds. Nat Areas J 26(3):280288. https://doi.org/10.3375/0885-8608(2006)26[280:TVOUFT]2.0.CO;2

Carrete M, Tella JL (2017) Behavioral correlations associated with fear of humans differ between rural and urban burrowing owls. Front Ecol Evol 5:54. https://doi.org/10.3389/fevo.2017.00054

Carrs DN, Kruuk H, Conroy JWH (1990) Predation on adult Atlantic Salmon, Salmo salar, by otters Lutra Iutra within the River Dee system, Aberdeenshire, Scotland. J Fish Biol 37:935-

944. https://doi.org/10.1111/j.1095-8649.1990.tb03597.x

Castillo-Contreras R, Carvalho J, Serrano E, Mentaberre G, Fernández-Aguilar X, Colom C, González-Crespo C, Lavín S, López-Olvera JR (2018) Urban wild boars prefer fragmented areas with food resources near natural corridors. Sci Total Environ 615:282-288. https://doi.org/10.1016/j.scitotenv.2017.09.277

Charmantier A, Demeyrier V, Lambrechts M, Perret S, Grégoire A (2017) Urbanization is associated with divergence in pace-of-life in great tits. Front Ecol Evol 5:53. https://doi.org/10.3389/fevo.2017.00053

Clavero M, Prenda J, Delibes M (2003) Trophic diversity of the otter (Lutra lutra L.) in temperate and Mediterranean freshwater habitats. J Biogeogr 30:761-769. https://doi.org/10.1046/j.13652699.2003.00865.x

Clavero M, Prenda J, Delibes M (2005) Amphibian and reptile consumption by otters (Lutra lutra L.) in a coastal area in southern Iberian Peninsula. Herpetol J 15:125-131

Clavero M, Prenda J, Delibes M (2007) Does size matter? Relating consumed prey sizes and diet composition in south Iberian coastal streams. Acta Theriol 52(1):37-

44. https://doi.org/10.1007/BF03194197

Colgâlniceanu D, Márquez R, Beltrán JF (2010) Impact of otter (Lutra lutra) predation on amphibians in temporary ponds in Southern Spain. Acta Herpetol 5(2):217-222

Díaz-Paniagua C (1983) Influencia de las características del medio acuático sobre las poblaciones de larvas de anfibios en la Reserva Biológica de Doñana (Huelva, España). Doñana Acta Vertebrata 10:41-53

Díaz-Paniagua C (1986) Reproductive period of amphibians in the Biological Reserve of Doñana (SW Spain). Pp. 429-432. En: Rocek, Z. (Ed.). Studies in Herpetology (Proceedings of the Third Ordinary General Meeting of the Societas Europaea Herpetologica). Charles University. Prague.

Díaz-Paniagua C (1992) Variability in timing of larval season in an amphibian community in SW Spain. Ecography 15:267-272. https://doi.org/10.1111/j.1600-0587.1992.tb00034.x

Delibes M, Ferreras P, Blázquez MC (2000) Why the eurasian otter Lutra lutra) leaves a pond? An observational test of some predictions on prey depletion. Rev Ecol (Terre Vie) 55:57-65 
Duarte J (2008) Atropellos de nutria en el entorno de campos de golf de Málaga. Galemys 20(1):105.

Duarte J, Rubio P (2005) Presencia de la nutria (Lutra lutra) en campos de golf en la Costa del Sol occidental, Málaga. VII Jornadas de la SECEM, Valencia, Diciembre 2005, pp. 64

Duarte J, Farfán MA, Vargas JM (2011) The use of artificial lakes on golf courses as feeding areas by the otter (Lutra lutra) in southern Spain. IUCN OSG Bulletin 28 (1):17-22

Duarte J, Farfán MA, Fa JE, Vargas JM (2015) Deer population inhabiting urban areas in the south of Spain: habitat and conflicts. Eur J Wildl Res 61:365-377. https://doi.org/10.1007/s10344-015-0902-z

Fischer JD, Cleeton SH, Lyons TP, Miller JR (2012) Urbanization and the predation paradox: The role of trophic dynamics in structuring vertebrate communities. BioScience 62:809-

818. https://doi.org/10.1525/bio.2012.62.9.6

Fowler J, Cohen L (1992) Practical statistics for field biology. Wiley \& Sons

García P, Ayres C (2007) Depredación masiva de la nutria (Lutra lutra) sobre el galápago leproso (Mauremys leprosa). Munibe 25:44-49

Gloor S, Bontadina F, Hegglin D, Deplazes P, Breitenmoser U (2001) The rise of urban fox population in Switzerland. Mamm Biol 66:155-164. https://doi.org/10.5167/uzh-141504

Jiménez J, López-Martín JM, Ruiz-Olmo J, Delibes M (2008). ¿Por qué se está recuperando la nutria en España? In: López-Martín JM, Jiménez J (eds) La nutria en España. Veinte años de seguimiento de un mamífero amenazado. SECEM, Málaga, pp 273-304

Koehn JD (2004) Carps (Cyprinus carpio) as a powerful invader in Australian waterways. Freshw Biol 49:882-894. https://doi.org/10.1111/j.1365-2427.2004.01232.x

Kruuk H (2006). Otters. Ecology, behaviour and conservation. Oxford University Press

Lizana M, Pérez-Mellado V (1990) Depredación por la nutria (Lutra lutra) del sapo de la sierra de Gredos (Bufo bufo gredosicola). Doñana Acta vertebrata 17(1):109-112

Llinares A, Martínez-Abraín A, Veiga J (2019) High foraging efficiency of Eurasian otters in a shallow Iberian reservoir. Wildlife Biol wlb.00589. https://doi.org/10.2981/wlb.00589

Martínez-Abraín A, Jiménez J (2016) Anthropogenic areas as incidental substitutes for original habitats. Conserv Biol 30(3):593-8. https://doi.org/10.1111/cobi.12644

Martínez-Abraín A, Jiménez J, Oro D (2018) Pax Romana: 'refuge abandonment' and spread of fearless behavior in a reconciling world. Anim Conserv 22(1):3-13. https://doi.org/10.1111/acv.12429 
Martínez-Abraín A, Jiménez J, Oro D (2019) New policies for a new wildlife: A road map for the wildlife manager of the future. Biol Conserv 236:484-488. https://doi.org/10.1016/j.biocon.2019.06.011

Martínez-Abraín A, Santidrián P, Veiga J (2020) Otter diet changes in a reservoir during a severe autumn drought. J Mammal 101(1):211-215. https://doi.org/10.1093/jmammal/gyz185

Marzluff JM, Rodewald AD (2008) Conserving biodiversity in urbanizing areas: non traditional views from a bird's perspective. Cities and the Environment 1(2):6, 27

Morales JJ, Ruiz-Olmo J, Lizana M, Gutiérrez J (1998). Diferencias en la ocupación por la nutria paleártica (Lutra lutra) de lagunas y embalses de altitud en el centro y norte de la península Ibérica. Galemys 10(ne):253-264

Mougeot F, Rodríguez-Ramiro J (2019) Commensal association of the common kingfisher wit foraging Eurasian otters. Ethology 125(12):965-971. https://doi.org/10.1111/eth.12953

Richter-Boix A, Llorente GA, Montori A (2007) Hierarchical competition in pond-breeding anuran larvae in a Mediterranean area. Amphibia-Reptilia 28:247-261. https://doi.org/10.1163/156853807780202549

Rodewald AD, Arcese P (2017) Reproductive contributions of cardinals are consistent with a hypothesis of relaxed selection in urban landscapes. Front Ecol Evol 5:77. https://doi.org/10.3389/fevo.2017.00077

Rodewald AD, Gehrt SD (2014) Wildlife population dynamics in urban landscapes. In: McCleery RA, Moorman C, Peterson MN (eds) Urban Wildlife Conservation: Theory and practice. Springer, New York, pp 117-147

Ruiz-Olmo J, López-Martín JM, Palazón S (2001) The influence of fish abundance on the otter (Lutra lutra) populations in Iberian Mediterranean habitats. J Zool Lond 254:325-

336. https://doi.org/10.1017/S0952836901000838

Ruiz-Olmo J, Jiménez J (2008a) Ecología de la nutria en los ambientes mediterráneos de la península Ibérica. In: López-Martín JM, Jiménez J (eds) La nutria en España. Veinte años de seguimiento de un mamífero amenazado. SECEM, Málaga, pp 305-343

Ruiz-Olmo J, Jiménez J (2008b) Diet diversity and breeding of top predators are determined by habitat stability and structure: a case study with the Eurasian otter (Lutra lutra L.). Eur J Wildl Res 55(2):133144. https://doi.org/10.1007/s10344-008-0226-3

Ruiz-Olmo J, Jiménez JA, Chacón W (2007) The importance of ponds for the otter (Lutra lutra) during drought periods in Mediterranean ecosystems: a case study in Bergantes river. Mammalia 71(1-2):1624. https://doi.org/10.1515/MAMM.2007.003

Ruiz-Olmo J, Jiménez J, Margalida A (1998) Capture and consumption of prey of the Otter (Lutra lutra) in Mediterranean freshwater habitats of the Iberian Peninsula. Galemys, 10 (número especial):209-226 
Ruiz-Olmo J, Mañas F, Olmo-Vidal JM, Batet A (2003) Breeding of Otters (Lutra lutra L.) in the Wild in the Mediterranean Area. In: Conroy JWH, Gutleb AC, Ruiz-Olmo J, Yoxon GM (eds) Otter Conference. The return of otters: How and where? June, 2003, Skye island, Scotland

Ruiz-Olmo J, Margalida A, Batet A (2005) Use of small rich patches by Eurasian otter (Lutra lutra L.) females and cubs during the pre-dispersal period. J Zool Lond 265:339-

346. https://doi.org/10.1017/S0952836905006424

Shochat E, Lerman SB, Anderies JM, Warren PS, Faeth SH, Nilon CH (2010) Invasion, competition and biodiversity loss in urban ecosystems. BioScience 60(3):199-

208. https://doi.org/10.1525/bio.2010.60.3.6

The Gobal News (2020) Koi tremble in fear as otter makes reappearance in Vancouver Chinese garden. https://globalnews.ca/news/6118436/otter-returns-vancouver-garden/ Accessed 30/0302020

The Columbia Valley Pioner (2019) Otter 6, human 0: battle continues to outs koi muncher from Vancouver garden. https://www.columbiavalleypioneer.com/trending-now/otter-6-humans-0-battlecontinues-to-oust-koi-muncher-from-vancouver-garden/. Accessed 04/03/2019

The Wiltshire Times (2020) More than 20 fish were killed in otter raid on the Manor fishpond at Steele Ashton. https://www.wiltshiretimes.co.uk/news/18341832.20-fish-killed-otter-raids-manor-fishpondsteeple-ashton/. Accessed 02/04/2020

The Star (2020) Otters have splashing good time in fish ponds.

https://www.thestar.com.my/news/regional/2020/03/14/otters-have-splashing-good-time-in-fish-ponds. Accessed 30/03/2020

Sokal RR, Rohlf FJ (1995) Biometry, third edition. Freeman, New York

Thieme JL, Rodewald AD, Brown J, Anchor C, Gehrt SD (2015) Linking grassland and early successional bird territory density to predator activity in urban parks. Nat Areas J 35:515-

532. https://doi.org/10.3375/043.035.0404

White GC, Garrott RA (1990) Analysis of wildlife radio-tracking data. Academic, London

\section{Figures}




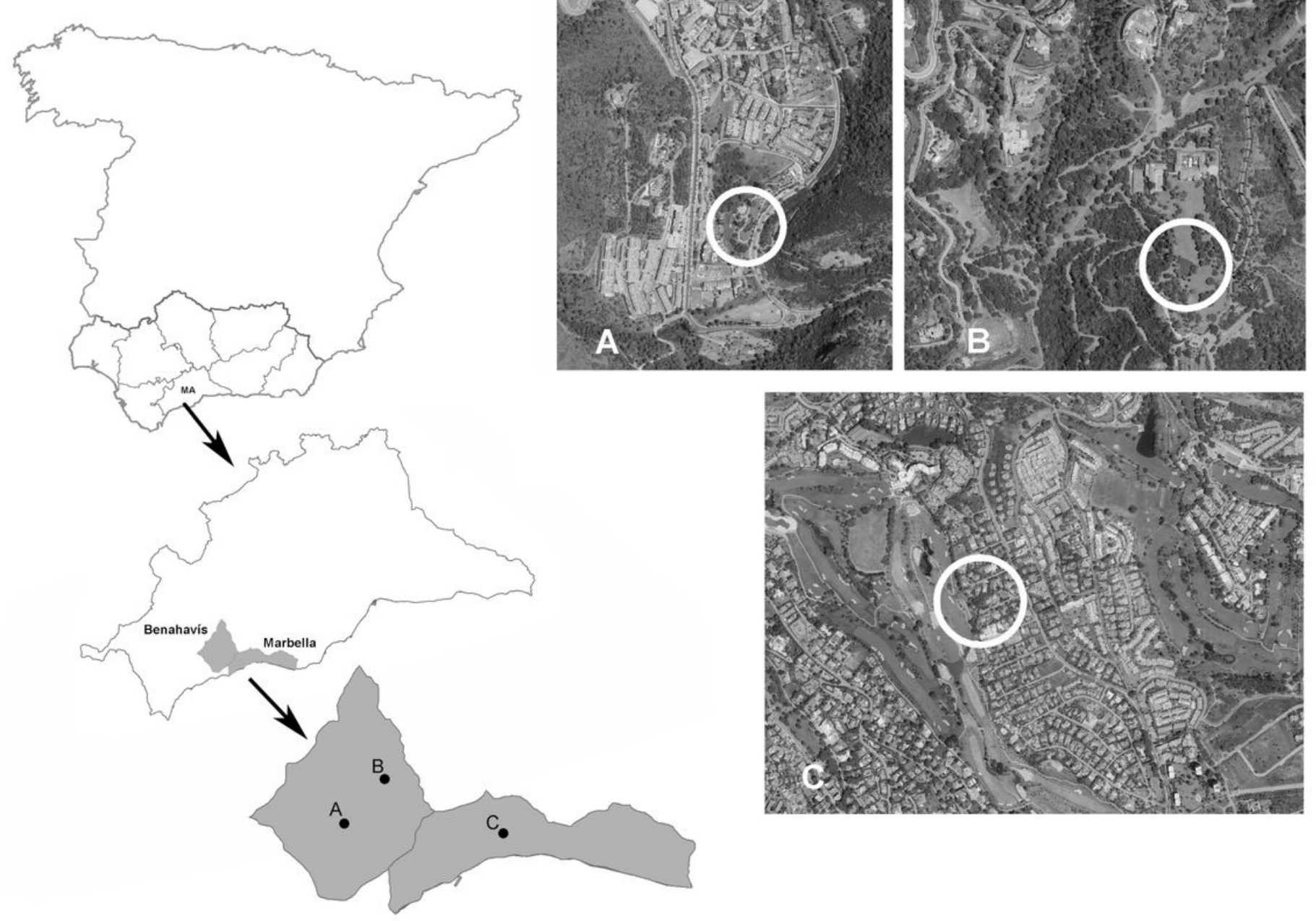

\section{Figure 1}

Study areas within the municipalities of Benahavís (Bhv) and Marbella (Mar) (Málaga, south of Spain). (A) Ponds at the "Torre Leoneras" park, Benahavís; (B) Pond at the "Campanillas" private estate; (C) Pond at the "Nueva Andalucía" private estate 


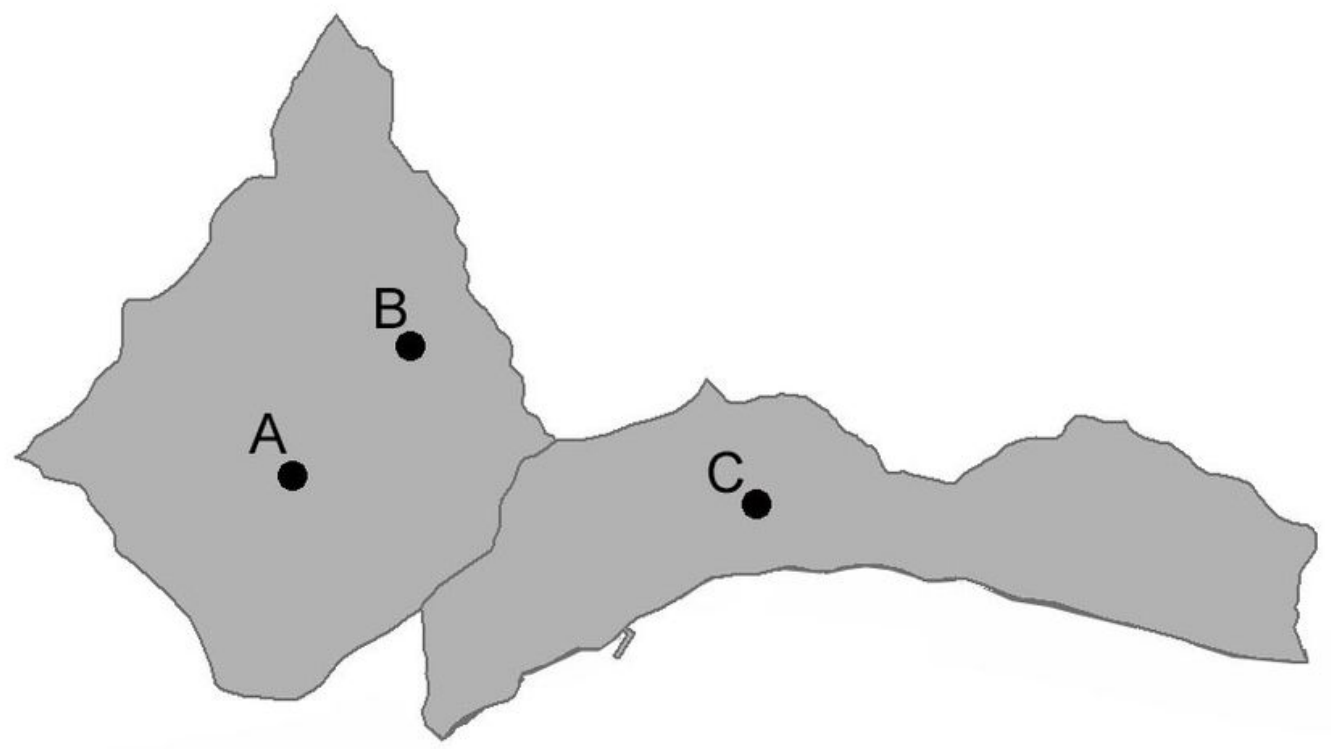

Figure 2

Kaplan-Meier survivor functions of carps in urban park ("Torre Leoneras") ponds during the study period 


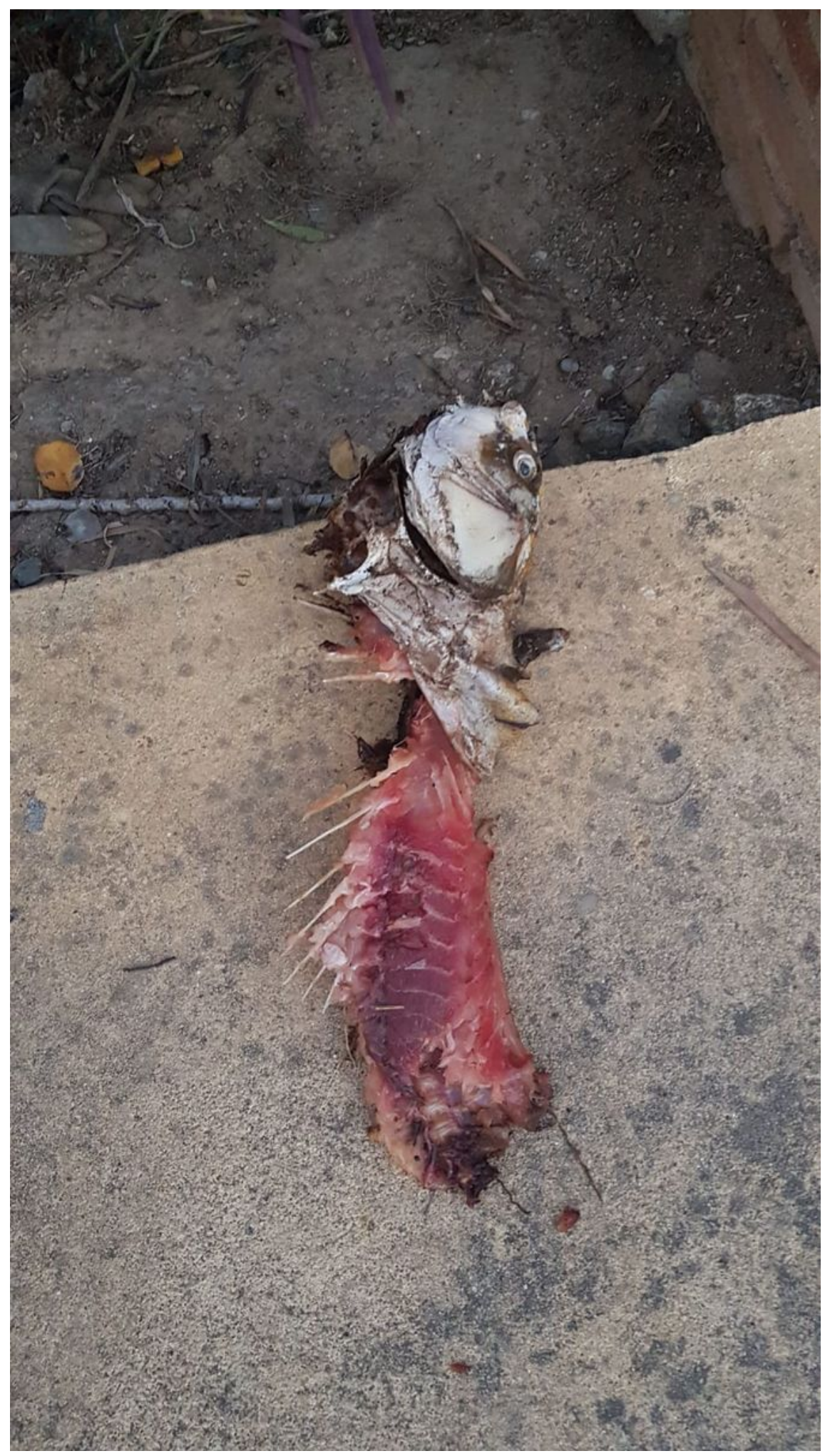

Figure 3

Koi fish carcass almost completely consumed by an otter 


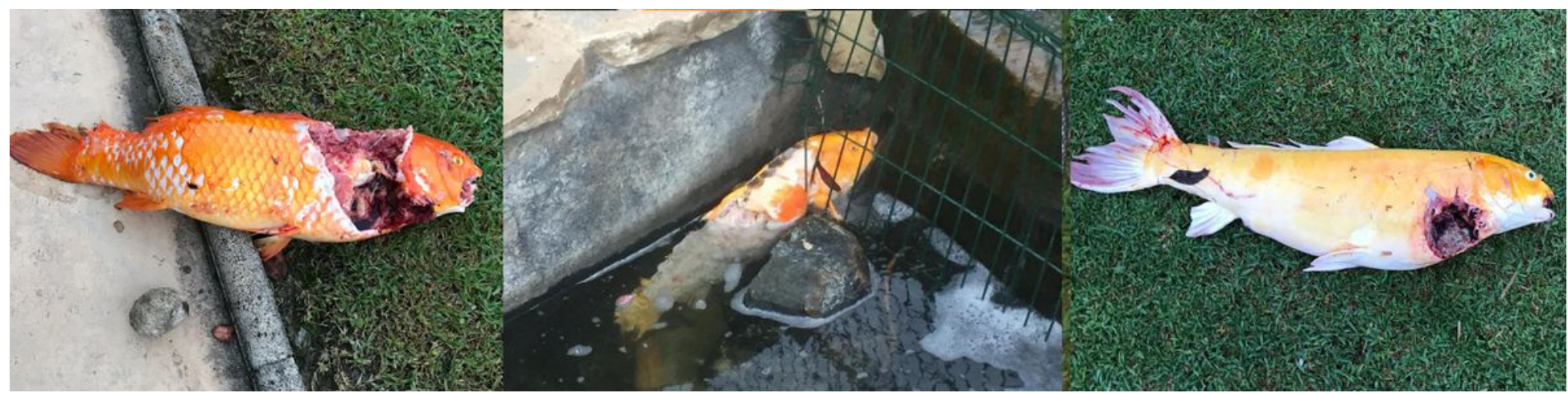

Figure 4

Koi fish carcasses skinned or partially consumed by otters

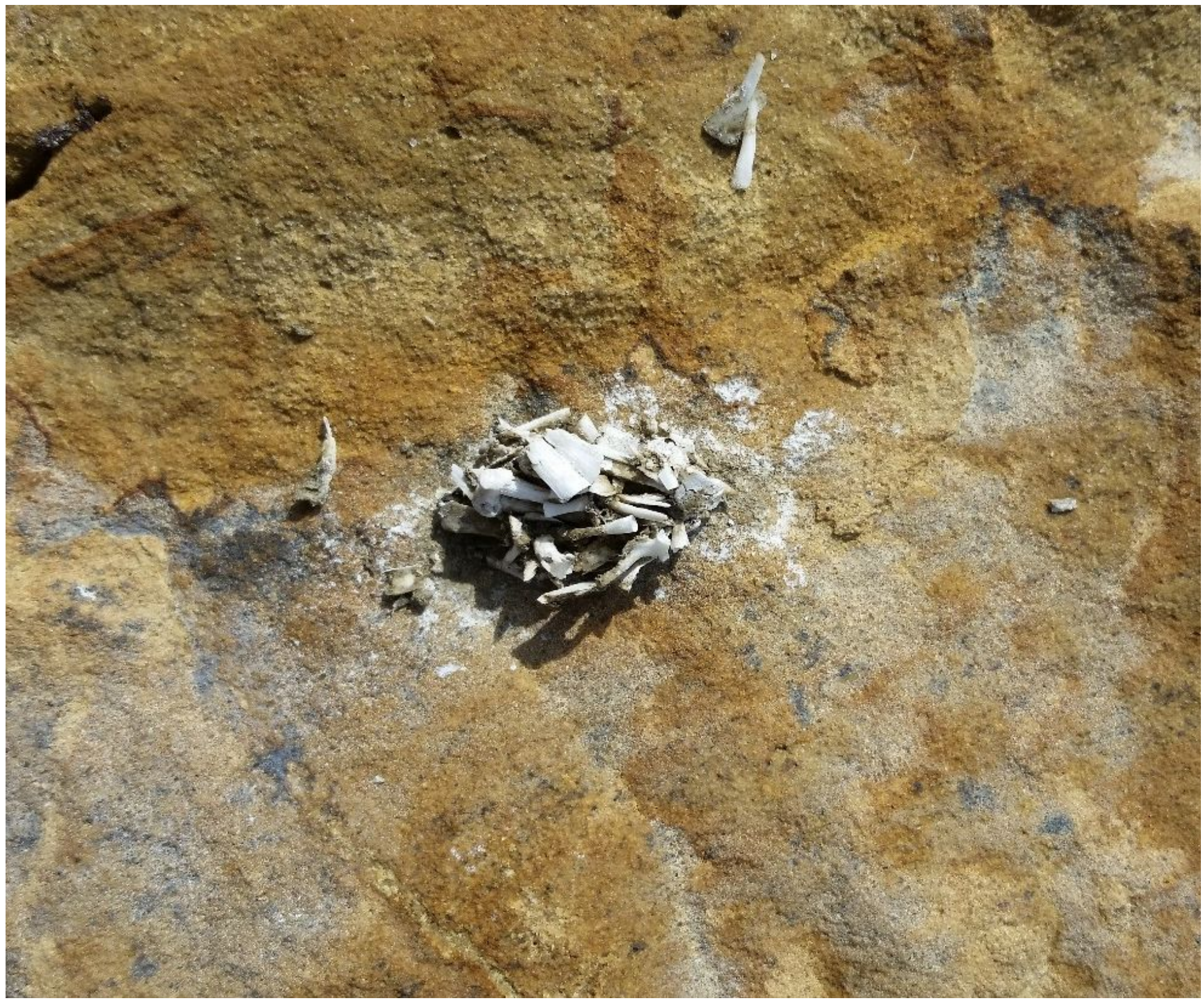

Figure 5 
Otter spraint with rest of frog bones found at the urban pond ("Campanillas").

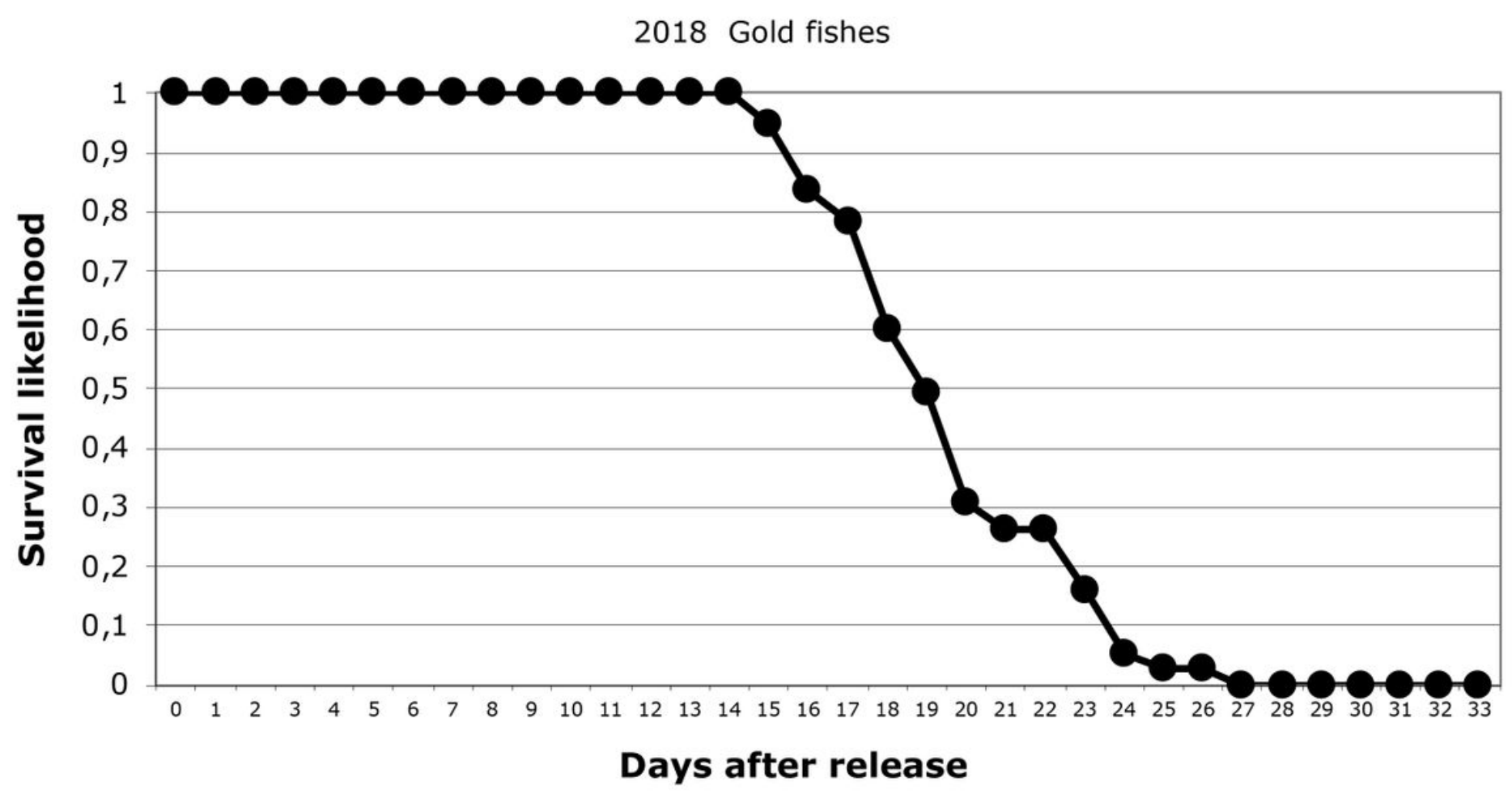

Figure 6

Kaplan-Meier survivor function of goldfish in an urban pond ("Nueva Andalucía") visited by otters 